\title{
Accumulation of radionuclide and metal contaminants in flesh and osteoderms of estuarine crocodiles (crocodylus porosus): Pathways and histories of catchment-specific exposure
}

\author{
R.A. Jeffree, S.J. Markich, K. Hammerton and R. Russell \\ Environment Division, ANSTO, PMB 1, Menai 2234, Australia
}

\begin{abstract}
Flesh and osteoderms of estuarine crocodiles (C. porosus) from Kakadu National Park, Northern Australia, were analysed for a range of metals, including uranium, to assess their capability for accumulation, in relation to their catchment-specific exposure to i) uranium mine effluents and mineralisation and ii) lead shot ammunition through their consumption of fauna shot by the traditional owners of the Park. Uranium in osteoderms was significantly $(\mathrm{P}<0.05)$ elevated in the East Alligator River catchment, that contains the Ranger and Jabiluka uranium mine sites, relative to two other adjacent catchments. The mean concentrations of other elements in flesh and osteoderms were also significantly $(\mathrm{P}<0.05)$ different between catchments. Linear discriminant analysis was used to demonstrate that multi-element signatures in both flesh and osteoderms could be used to classify individual crocodiles to their respective catchments. This approach may be useful for the identification of source catchments of itinerant 'nuisance crocodiles' that find their way into Darwin Harbour, close to dense human habitation. Lead concentrations were significantly $(\mathrm{P}<0.05)$ enhanced in flesh and osteoderms of crocodiles sampled within two areas hunted with guns using $\mathrm{Pb}$ ammunition. Enhanced ratios of $\mathrm{Pb}: \mathrm{Ca}$ in the annual laminations of their osteoderms are consistent with their history of continual exposure to elevated anthropogenic $\mathrm{Pb}$ sources. Subsequent experimental studies have demonstrated the ability of the crocodilian stomach to retain ingested $\mathrm{Pb}$ shot, that is readily solubilised and absorbed into the blood and then archived in the contemporary osteodermal lamination.
\end{abstract}

\section{INTRODUCTION}

Previous radioecological studies have been undertaken on Ra-226 kinetics in the fauna and flora of the Kakadu National Park (KNP), northern Australia, that are components of the diet of the traditional Aboriginal owners. These field and laboratory-based investigations were relevant to formulating standards for $\mathrm{Ra}-226$ in effluents that may be released from the Ranger Uranium Mine (RUM), and the subsequent monitoring of their levels in the flesh of freshwater bivalves [1-2].

Estuarine crocodiles (Crocodylus porosus), a protected species, are also consumed by the traditional owners of KNP, along with other fauna such as magpie geese, flying foxes and feral pigs that have been hunted within KNP with $\mathrm{Pb}$ shot ammunition. The consumption of these shot fauna by $C$. porosus led to concerns that they may be contaminated with $\mathrm{Pb}$. A program of sampling both crocodile osteoderms and edible flesh, over a wide size range from the three main catchments of KNP, provided samples for analysis of $\mathrm{Pb}, \mathrm{U}$ and a range of other elements [3]. 
This paper summarises the current status of our field studies and subsequent experimental investigations on $C$. porosus that are relevant to $\mathrm{U}$ radioecology, $\mathrm{Pb}$ toxicity, as well as wildlife management issues and environmental monitoring in these long-lived animals.

\section{EXPOSURE OF CROCODILES TO PB SHOT AMMUNITION}

\subsection{Field exposure}

Estuarine crocodiles occur widely throughout the world heritage-listed KNP in the Alligator Rivers Region of northern Australia. Two areas had very plausible exposure pathways of $\mathrm{Pb}$ to crocodiles from their ingestion of $\mathrm{Pb}$ ammunition, viz. a) via the observed consumption of fauna that had been shot with $\mathrm{Pb}$ ammunition, and also $\mathrm{b}$ ) their capture of healthy magpie geese, that are known to ingest shot while foraging for food and grit items [4]. Analysis of the $\mathrm{Pb}$ concentrations in osteoderm and flesh of 40 crocodiles sampled throughout KNP showed elevated levels $(\mathrm{P}<0.001)$ in both tissues from individuals in the two exposed habitats, relative to all other individuals. Analysis by secondary ion mass spectrometry (SIMS) of the $\mathrm{Pb}-208 / \mathrm{Ca}-42$ signal ratios across the osteodermal laminations of exposed crocodiles confirmed they were elevated and relatively constant [5]. These results suggested the following; a) the crocodilian digestive system can retain $\mathrm{Pb}$ ammunition following ingestion and solubilise and absorb it into the body, b) crocodiles were exposed to elevated $\mathrm{Pb}$ levels during most of their life, that they could apparently tolerate.

The following experiment was undertaken to evaluate these conclusions.

\subsection{Experimental exposure}

The crocodiles ( $C$. porosus) chosen for an experiment on the effects of exposure to $\mathrm{Pb}$ shot in food, were reared and housed at Crocodylus Park, near Darwin in the Northern Territory. They were randomly selected from a group of 2 to 3 year old juveniles with body lengths ranging from $1.5 \mathrm{~m}$ to $2.0 \mathrm{~m}$. All animals were administered with pebbles, as the stomachs of crocodilians are known to contain stones (gastroliths), thought to aid in the maceration of food [6]. As well, three animals received five $\mathrm{Pb}$ shot packaged into meat boluses. Blood samples were taken from test and control animals over a 20 -week period; blood was withdrawn from the post-occipital venous sinus into heparinised vacutainers. At 20 weeks a stomach lavage was performed on each animal in order to determine the retention and degree of dissolution of the $\mathrm{Pb}$ shot, after which the visceral region of each animal was radiographed. Blood samples were analysed for total $\mathrm{Pb}$ concentration using inductively coupled plasma mass spectrometry (ICP-MS).

Figure 1 shows the pattern of $\mathrm{Pb}$ concentration in blood samples taken from one specimen over 141 days, that is typical of crocodiles that have ingested five lead pellets. A one compartment model with first order loss kinetics is fitted to these data. The $\mathrm{Pb}$ concentration immediately increases following ingestion and appears to have reached an equilibrium concentration in 30-40 days of c. $350 \mu \mathrm{g} \cdot \mathrm{dL}^{-1}$, which is an increase above background of more than an order of magnitude. This result confirmed the ability of the digestive system of $C$. porosus to solubilise $\mathrm{Pb}$ from the ingested shot and absorb it into the blood at a rapid rate. The subsequent lavage and radiography of the stomachs of exposed crocodiles retrieved or identified more than $70 \%$ of the individual ingested $\mathrm{Pb}$ shot pellets, confirming their ability to retain $\mathrm{Pb}$ shot [7]. 


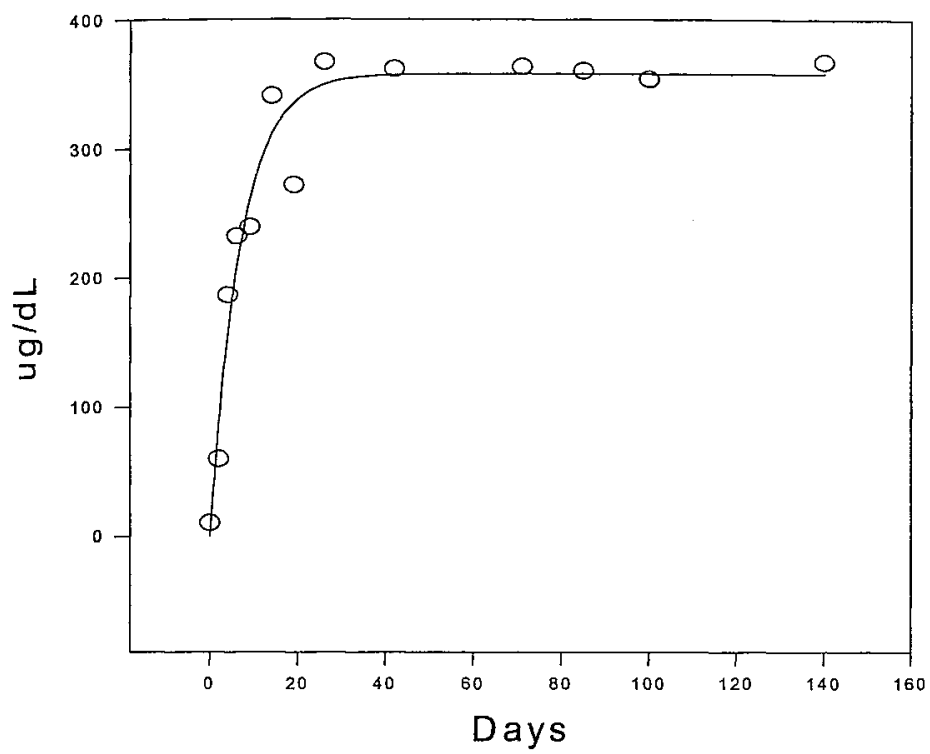

Figure 1: Pattern of $\mathrm{Pb}$ concentration ( $\mu \mathrm{g} / \mathrm{dL}$ ) in the blood of $C$. porosus plotted against time (days) following ingestion of $\mathrm{Pb}$ shot pellets (five).

\subsection{Osteoderms as archives of experimental exposure}

These experimental findings made it then possible to evaluate the hypothesis that the osteodermal laminations would record enhanced blood $\mathrm{Pb}$ concentrations resulting from the ingestion of $\mathrm{Pb}$ shot. At about 140 days following $\mathrm{Pb}$ shot ingestion two osteoderms were removed from each exposed and control animal. SIMS analysis of $\mathrm{Pb}-208$ and $\mathrm{Ca}-42$ signal intensities was then performed on sections that were prepared and analysed using similar methods previously used on field-collected specimens [3]. Figure 2 shows SIMS line scans for these two isotopes, that begin in the skin (0) in which the osteoderms are constructed and move through the skin/bone interface $(\sim 100 \mu \mathrm{m})$, through the most recently deposited laminations to those progressively constructed at greater periods prior to experimental treatment $(>100$ to $200 \mu \mathrm{m}$ ), for both a control specimen (i) and one that had ingested five $\mathrm{Pb}$ shot (ii). For both specimens, the Ca signal increases through the skin/bone interface to remain elevated through the rest of the osteodermal laminations. However for $\mathrm{Pb}$, the signal is relatively constant throughout the control section but in the $\mathrm{Pb}$-exposed animal 
shows an increase in signal intensity by more than an order of magnitude through the skin/bone interface and most recently constructed laminar material, before declining by an order of magnitude in the previously constructed laminations of the osteoderm.

These initial findings are consistent with the hypothesis that incremental laminations of the osteoderm will archive a $\mathrm{Pb}$ signal that responds to enhanced levels of $\mathrm{Pb}$ in the animal's blood during its life.
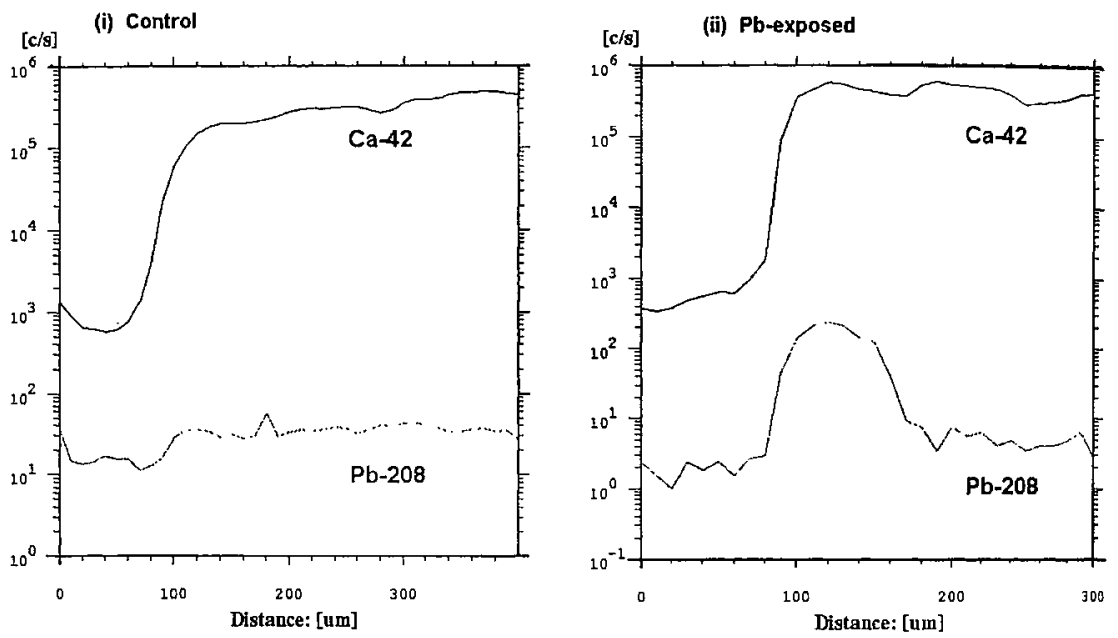

Figure 2. SIMS line scans of $\mathrm{Ca}-42$ and $\mathrm{Pb}-208$ signals across the skin and laminated osteoderm from C. porosus (i) unexposed and (ii) exposed to $\mathrm{Pb}$ shot ammunition previously ingested with food.

\section{ELEMENTAL CHEMISTRY OF CROCODILE OSTEODERMS AND FLESH}

\subsection{Size and age effects}

Among a range of elements that were detected in osteoderms and flesh the following relationships were found with either total length or estimated age. The $\mathrm{Mg}$ concentration $\left(\log _{10}\right)$ in both tissues significantly $(P \leq 0.001)$ decreased with increasing length $(1.7-5.0 \mathrm{~m})$ and estimated age (5-40 years). Similarly, the Ti concentration $\left(\log _{10}\right)$ in flesh significantly $(P \leq 0.01)$ decreased with increasing length. In contrast, $\mathrm{Zn}$ and Se concentration ( $\left.\log _{10}\right)$ in flesh significantly $(P \leq 0.001)$ increased with length and/or age. These relationships are probably mediated by biological rather than environmental chemical factors [5]. Further analysis by proton beam X-ray emission (PIXE) of the individual annual laminations of an osteoderm have indicated an increase in $\mathrm{Zn}$ concentration from the primordial to most recently deposited material [8], a result consistent with that for $\mathrm{Zn}$ in flesh.

\subsection{Catchment-specific effects}

For flesh, mean concentrations of $\mathrm{Al}, \mathrm{Ba}, \mathrm{Ni}$ and $\mathrm{Pb}$ were significantly $(\mathrm{P} \leq 0.05)$ higher in crocodiles from the Wildman/West Alligator river catchment relative to one or both of the other two catchments. The mean $\mathrm{Cr}$ concentration however, was highest in the South Alligator river catchment. In osteoderm there was no obvious prominence of one catchment having repeatedly higher concentrations of elements, relative to the others. Whereas $\mathrm{Mn}$ concentration was higher $(\mathrm{P} \leq 0.05)$ in samples 
from the Wildman/West Alligator river catchment relative to the South Alligator river catchment, $\mathrm{Fe}$ was significantly $(\mathrm{P} \leq 0.05)$ elevated in the East Alligator river catchment samples relative to those from the Wildman/West Alligator river catchment. Uranium was the only element that showed significantly $(P \leq 0.05)$ different means between each pair of catchments, being highest in the East Alligator river catchment, that contains the Ranger and Jabiluka uranium mine sites, and lowest in the Wildman/ West Alligator river catchment [5].

These significant $(P \leq 0.05)$ effects of catchment on the concentrations of various elements indicate that $C$. porosus reflects the chemistry of its environmental milieu and therefore has a certain degree of catchment fidelity. Such catchmentspecific signals may be useful in the determination of the provenance of itinerant crocodiles that may cause social concern in populated and recreational areas $[9,10]$. They also point to the utility of crocodiles as long-term biomonitors of their environment.

\section{Acknowledgements}

The Biodiversity Group of Environment Australia is thanked for the sampling of osteoderms and flesh from crocodiles in KNP.

\section{References}

[1] Jeffree R. A. Hydrobiologia, 218(3) (1991), 205-233.

[2] Twining J. R.. J Environ Radioact 20 (1993), 169-189.

[3] Twining J. R., Markich S. J., Prince K. E. and Jeffree R. A. Environ. Sci. Technol 33 (1999) 4396-4400.

[4] Whitehead P. J. and Tschirner K. Biol. Conserv. 58 (1991) 99-118.

[5] Jeffree R. A., Markich S. J. and Twining J. R. Arch. Environ. Contam. Toxicol. 40 (2001) 236-245.

[6] Skoczylas R. Physiology of the Digestive Tract in Biology of the Reptilia, vol. 8 eds Gans C. \& Gans K. A., Academic Press, London, 1978, pp. 589-717.

[7] Jayasinghe N., Hammerton K., Jeffree R. A. and Lim R. (in prep).

[8] Orlic I., Siegele R., Menon D. Dev, Markich S J., Cohen D. D. , Jeffree R. A., McPhail D. C., Sarbutt A., Stelcer E., Nucl. Instrum.\& Methods. B. (submitted).

[9] Northern Territory News 2001, May 24.

[10] Markich S. J., Jeffree R. A. and Harch B. The Science of the Total Environment (in press). 